\title{
Range Management Schools for Ranchers: Or How to Teach Plant Phenology, Forage Utilization, Plant Physiology and Other Esoteric Range Management Concepts to a Bunch of Cowboys
}

\author{
Robbie Baird LeValley, John Murray, Floyd Reed, John Hawks and David Bradford
}

$\mathrm{W}$ estern Colorado, like many parts of the West, has experienced conflict over livestock grazing on public rangelands. This conflict has often created discord, uncertainty and stress. The early 1990's were very troubling times for public lands ranchers. It was in this atmosphere of apprehension that public land ranchers of the Uncompahgre Basin began asking for help in learning what was expected of them. In response to these requests Colorado State University Cooperative Extension in 1995 brought together representatives from the Natural Resources Conservation Service (NRCS), the U.S. Forest Service (FS) and the Bureau of Land Management (BLM) to develop a range management training program for ranchers. The agency representatives identified key permittees who were interested in getting more information on the science and practical application of progressive range management. Eighteen producers were invited to help determine the curriculum content. From this initial meeting developed the idea of the Range Management School for Ranchers.

The permittees told us what they wanted. They wanted details. They did not want the basics; however, they also did not want to be overwhelmed with scientific jargon. They wanted information that would help them understand what was happening on the range. They wanted to know how to evaluate the range and how to influence conditions. They wanted information that would help them defend their livelihood. They asked for material that would be presented in a concise form with an emphasis on fieldwork that demonstrated the class room instruction. They asked that the government agency people also attend the sessions - so that everyone involved in the on-the-ground management was hearing the same things. With these sideboards, the Range Management School for Ranchers was developed. Two courses, the introductory course-Range 101, and a more advanced course-Range 501, were set up to meet the ranchers' requests.

The first Range 101 course was held in December 1995. Sixty-two grazing permittees, federal land managers, private

\begin{tabular}{|ll}
\hline Range 101 Curriculum & Range 501 Curriculum \\
\hline Grass Plant Physiology & Plant Identification \\
\hline Plant Phenology & Designing a Grazing Plan \\
\hline Grazing Responses & Range Health Indicators \\
\hline Range Nutrition & Plant Growth Curves \\
\hline Rangeland Monitoring & Biological Planning \\
\hline & Grazing Response Index \\
\hline
\end{tabular}

rangeland owners and environmentalists attended. The class consisted of two days of classroom instruction and two days of field instruction. Subjects covered in the classroom included plant identification, how a grass plant grows, plant responses to grazing, range nutrition, biological planning, range monitoring, animal behavior, range economics, range improvements and poisonous plants. The field session emphasized plant identification and on-the-ground examples where improved management had resulted in significant improvements.

The Range 501 course was held the following spring of 1996, with the same participants returning. In the more advanced 501 class, we went into the details of designing a grazing management plan. This included what the federal agencies require-carrying capacity, trends, rangeland monitoring, grass growth curves, and biological planning. The participants were required to develop a grazing plan on an actual allotment with all of the resource concerns and landscape characteristics of that allotment. The participants then had to present their plans to the class. This proved to be an invaluable exercise. The field session for Range 501 included a trip to the allotment that they worked on in class, additional plant identification and areas where changes were being made on the time and timing of grazing.

Each course participant received a resource notebook. The information contained in the notebook included material from Colorado State University Rangeland Ecosystem Science Department, pertinent articles from Rangelands and the Journal of Range Management, NRCS publications, reports from the USDA-ARS Poisonous Plant Lab and speakers handouts. The publication Grass: The Stockman's Crop by Harland Deitz is particularly useful. The cost of the notebooks was covered in part by a Renewable Resources Extension Act grant. The cost to each participant was $\$ 15$ per session.

We went back to the course participants and asked them for a critique of the courses. The result of that survey was that some topics were deleted and each course was condensed down to one day. However, we found that we were right-on with the focus of the schools - to provide in-depth range education via classroom instruction, field tours and practical application. The newly formatted classes were presented in Gunnison and Norwood, Colorado in January 1996. The revised sessions included the subjects of grass growth, plant responses to grazing, grass growth curves, range nutrition, the time and timing of grazing, rangeland monitoring, indicators of range health, grazing response index, and designing a grazing plan. The field sessions followed in September 1996 and again looked at areas where improved management has taken 


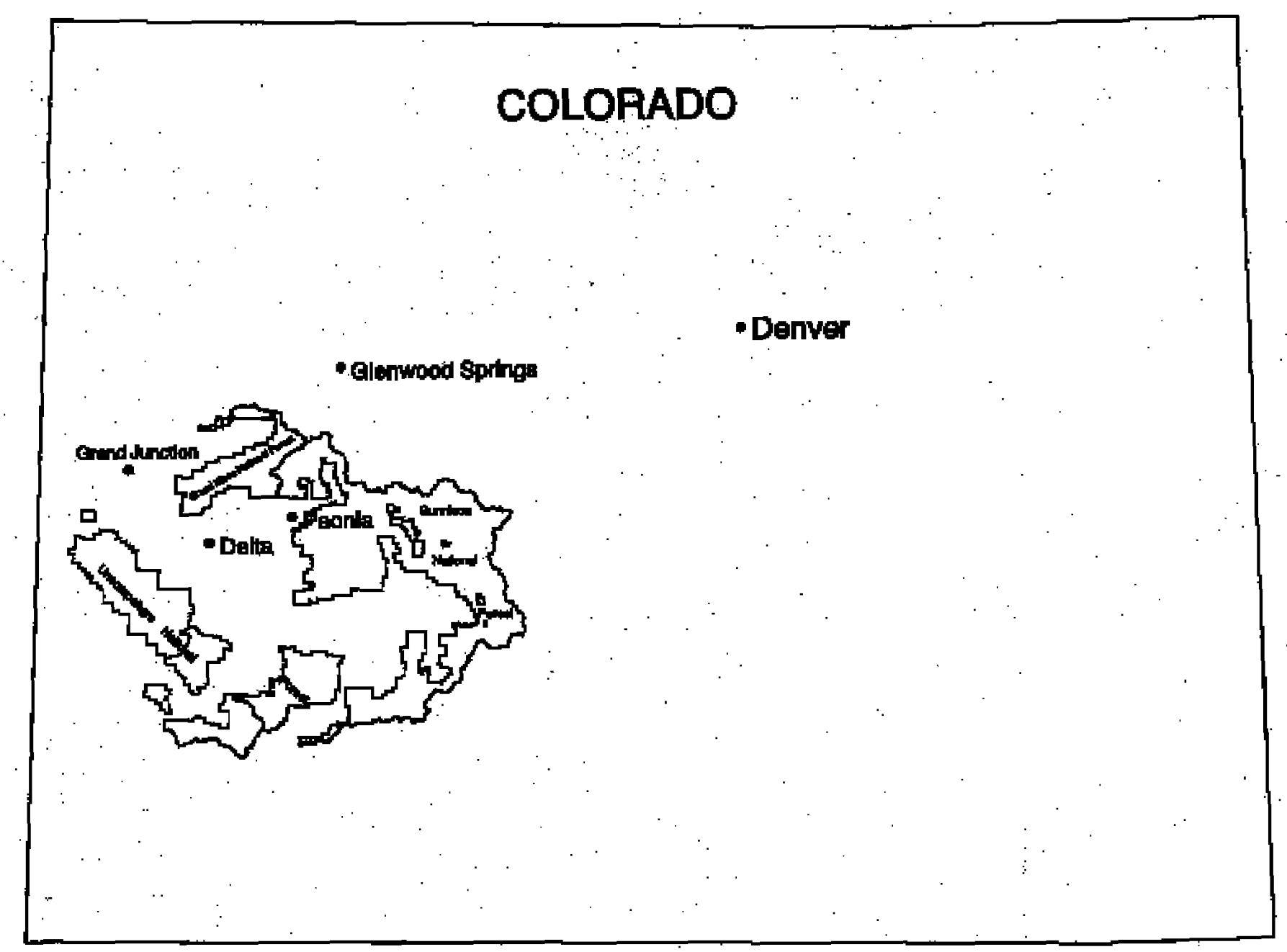

place. We received positive feedback on both these sets of courses.

With the positive responses for these first four schools and additional requests from other ranchers in the area, courses have also been taught in Rifle, Colorado in November 1997, Steamboat Springs, Colorado in December 1997, and again in Delta/Montrose, Colorado in December 1997. A 1998 total of 410 permittees, federal land managers, environmentalists and private rangeland owners have attended the Range Management Schools (RMS) since their inception in 1995. Pre and post-course evaluations have shown an average $34 \%$ increase in knowledge gained from the RMS. The range management school idea has spread to other parts of Colorado. In Southeast Colorado, Regional Range Specialist, Tim Steffens is teaching a grazing school over a six-week period. But the bigger story is what is happening on the ground.

Dozens of grazing allotments on the Grand Mesa, Uncompahgre and Gunnison National Forests have initiated significant changes in management on their allotments. The same is true for BLM allotments on the Uncompahgre Resource Area. A number of grazing permittees have initiated their own monitoring programs. Colorado State University Cooperative Extension assists the permittees in the first three years in setting up and developing their monitoring program. In fact the response has gotten so strong that it is a major challenge to the Forest Service and BLM to keep up with all the proposed management changes. (See related article on the West Terror allotment).

\section{The Dry Fork Allotment}

One specific example of ranchers who have initiated changes in their management is the Dry Fork Livestock Association. The Dry Fork Allotment is located near Paonia, Colorado and borders the West Elk Wilderness. This group of four ranchers historically grazed 405 cow/calf pairs on four areas/allotments from May 15 to October 15.

Some of the areas/allotments were grazed for the entire grazing period while some were split into pastures. For the most part, grazing periods were 30 days long. This had resulted in the typical pattern of over-grazed/under-grazed areas. The over-grazed areas had low plant diversity, reduced plant density and low plant vigor. They also looked bad. The undergrazed areas were over-rested-usually showing a significant accumulation of plant litter, reduced plant diversity and reduced plant vigor.

In January 1996, after participating in the Range Management School the permittees proposed a number of management changes on the allotments. The changes involved creating smaller grazing units and grazing these units with larger numbers of cattle for shorter periods of time. Taking 
advantage of natural barriers and temporary electric fence reated most of these units. The current management system uses 25 grazing unis, with grazing periods varying from 5 to 22 days.

These changes have provided a number of benefits - most notably there is a more even utilization of forage plants on the range and grazed plants were given the opportunity to grow before grazing occurs or to regrow after grazing. This has resulted in improved plant density, vigor and diversity. This management strategy has also provided more flexibility, as the increase in grazing units has given the permittees more control of their cattle and allows them to make easier adjustments due to cold weather, drought, poisonous plants, etc.

\section{The Dominguez Allotment Example}

Another specific example of a change based on the principles learned in the Range Management School are the Dominguez, Smith Point and Ridge allotments on the Uncompahgre Plateau. Historically, these allotments were managed separately. The allotments were grazed by three separate herds of cattle using a 5-pasture, a 4-pasture and a season-long management system, respectively. After attending the Range Management School, the permittee who ran on these three allotments, understood the concepts when the Forest Service proposed combining them into one allotment and grazing them with one herd of cattle. Beginning the summer of 1998, this combined allotment has been grazed by 1,000 cow/calf pairs, June $1-$ October 30 . The new management approach calls for cattle to be grazed as a single herd in 10 separate pastures, with grazing periods from 15 to 20 days. Pasture moves are based on grass growth.

\begin{tabular}{|lcc|}
\hline \multicolumn{3}{|c|}{ Historic Management } \\
\hline $\begin{array}{l}\text { Area/Allotment: } \\
\text { Grazed: }\end{array}$ & Livestock \#'s: & Period \\
\hline Jumbo Mountain - BLM & 30 Cow/calf pairs & $5 / 15-9 / 13$ \\
\hline Lion's Mesa - Private & 85 Cow/calf pairs & $5 / 15-6 / 15$ \\
\hline Oak Ridge - BLM & 163 Cow/calf pairs & $5 / 15-6 / 15$ \\
\hline & 163 Cow/calf pairs & $10 / 16-10 / 30$ \\
\hline Dry Fork - FS & 405 Cow/calf pairs & $6 / 16-10 / 16$ \\
\hline
\end{tabular}

These changes are making a difference on the ground and improving relationships between the federal land management agencies and permittees. Testimonials include the following:

"This can only result in healthier local communities and enhanced environmental conditions on the public and private rangelands here on the Western Slope."

"It made me more aware of the need for information to work the land. Information is very important in the use of this system."

"Excellent sessions—really got something."

"Those who criticize grazing on public lands must learn that as a use, grazing can be organized to improve range condition."

In January of 2000, Range 701 was offered. Sixty-five per-

\begin{tabular}{lll}
\multicolumn{3}{c}{ Current Management } \\
\hline $\begin{array}{l}\text { Area/Allotment: } \\
\text { Grazed: }\end{array}$ & Livestock \#'s: & Period \\
\hline Jumbo Mountain - BLM & 196 Cow/calf pairs & 5/10-6/24 \\
\hline Lion's Mesa - Private & 373 Cow/calf pairs & $6 / 15-6 / 24$ \\
\hline Oak Ridge - BLM & 288 Cow/calf pairs & $5 / 10-6 / 14$ \\
\hline Dry Fork - FS & 584 Cow/calf pairs \\
\hline & 45 Yearlings & $6 / 25-10 / 19$ \\
\hline
\end{tabular}

mittees and federal land managers attended. Topics included grass growth curves, integrated forage systems, range nutrition, wildlife use and managing with wildlife. Pre and post evaluations of the course indicated a $32 \%$ increase in knowledge and understanding of range management. Future plans include starting a range focus group and additional field trips.

\section{Collaboration improves the resource and relationships}

Does the Range Management School approach work? The on-the-ground examples and the acceptance into other parts of the state would indicate it does. Variations of the course have been taught in the Southeast and Northwest corners of Colorado. Inquiries about the school have been received from Wyoming, New Mexico and California. The strength of the schools is that participants hear the same messages in the class and on the ground. It is backed up when they actively participate in the planning of their allotment with their range conservationist. The collaborative approach works for the resource and the relationships.

The Range Management Schools for Ranchers have worked because there is a good working relationship between the permittees, the federal land management agencies and the university to provide information that ranchers need and have requested. The permittees helped develop the curriculum and have input into changes. (Changes are considered as long as the overall goal of the course continues to be met.) Ranchers are hearing the same message from the NRCS, the FS, the BLM and the University. With the mix of instructors there is a strong sense of camaraderie and cooperation. There is a common understanding of what to do and what can be expected. The tie between animal nutrition and improved management is an especially important link, that ranchers have generally not heard before. The ranching community feels more stable and less threatened. The federal agencies have worked well together to offer the courses and then back it up when they are in the field. The permittees have seen the improvement on the range and have a better understanding as to why the changes are occurring and what can be done to continue the improvement. Including the environmentalists in the courses has significantly improved relationships as well. Their understanding has increased and the shared experiences of the classes have eliminated "us-versus-them" attitudes. The Range Management Schools for Ranchers have produced a win-win opportunity in the rangeland conflict in Western Colorado. 


\section{Resource Notebook Bibliography}

Trlica, M.M. Grass growth and response to grazing, No. 6.108, Colorado State University Cooperative Extension 6/96, Natural Resources Series.

Roath, L. Roy. Designing Grazing Management Programs, Department of Range Science, Colorado State University.

Bartlett, E. T. and Rittenhouse, L.R., 1989. Stocking Rates and Grazing Systems: Where Are the Profits?, Department of Range Science, Colorado State University.

Roath, L.R. and Rittenhouse, L.R.. Managing Grazable Forages During Fall and Winter, Department of Range Science, Colorado State University.

Roath, L. R. An Evaluation of Short Duration Grazing, Department of Range Science, Colorado State University.

Torrell, L. Allen and Hart, Richard H., 1988. Economic Consideration for Efficient Stocking Rates on Rangeland, Montana Agr. Exp. Sta., Bozeman.
Simonds, Gregg, 1991. Matching Cattle Nutrient Requirements to a Ranch's Forage Resource, or "Why We Calve Late", The Range Beef Cow Symposium XII, Fort Collins, CO.

Dietz, Harland E. 1988,1989. Special Report, Grass: The stockman's crop, How to harvest more of it, USDA Natural Resources Conservation Service.

Waller, Steven S., Moser, Lowell E., and Reece, Patrick E. 1985, Understanding Grass Growth: The Key to Profitable Livestock Production.

Authors are Livestock and Range Specialist for the Tri-River Area, Colorado State University Cooperative Extension, Delta, Colorado; Range Conservationist, Natural Resources Conservation Service, Montrose, Colorado; Range Staff Officer, Grand Mesa, Uncompahgre and Gunnison National Forest (GMUG NF), Delta, Colorado; retired Range Technician, BLM Uncompahgre Resource Area, Montrose, Colorado; and Range Conservationist, Paonia Ranger District, GMUG NF, Paonia, Colorado.

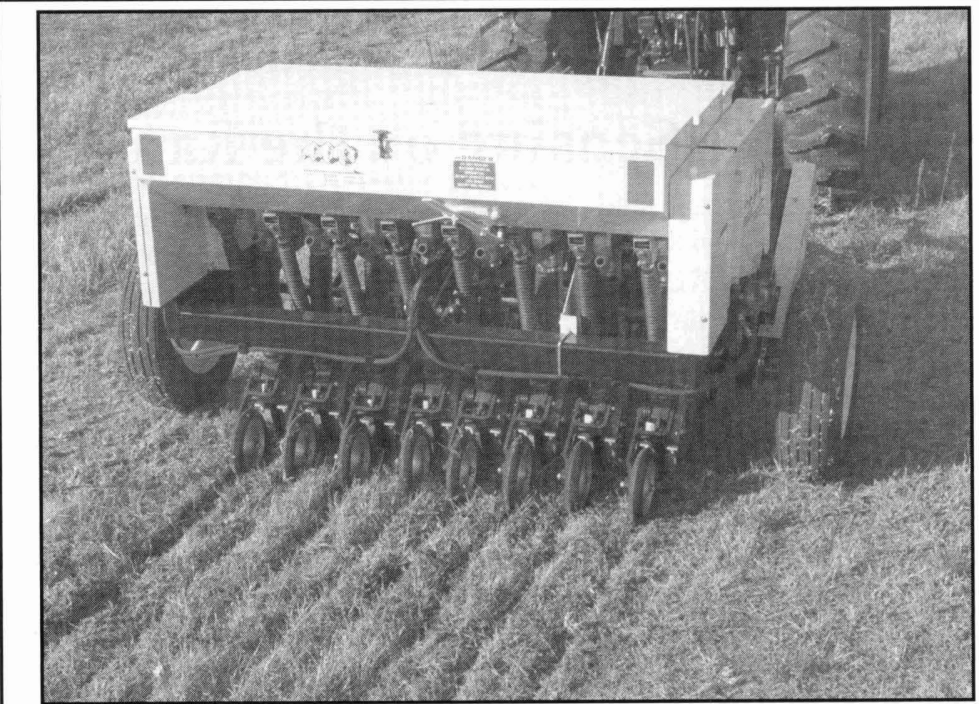

TTU The "Trillion" - shown at right, is the ideal

11 broadcast seeder for wildflowers, turf grasses, and fluffy/chaffy prairie seeds. Unit has three types of seed boxes and combines the truax seed delivery system with two Brillion ${ }^{\circledR}$ cultipack rollers.

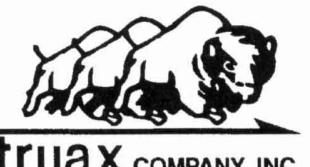

4821 Xerxes Ave. No., Bldg. B Minneapolis, MN 55430
For more information call (763) 537-6639 or visit www.truaxcomp.com

\section{PERFORMANCE.}

Superior design, top-quality materials, and meticulous hand-built construction are what set truax seeding equipment apart from the competition. You'll find these in every truax seeder from the small, hand-cranked, Seed Slinger that lets you broadcast fluffy seeds and grasses together by hand, to the famous Flex II seed drill pictured at left, which interseeds native grasses, turf grasses, fluffy seeds, small grains, wildflowers, even legumes.

The result is outstanding seeding performances even in the most challenging environments! and durability that will last for decades.

If you want dependable seeding performance, you want a truax!

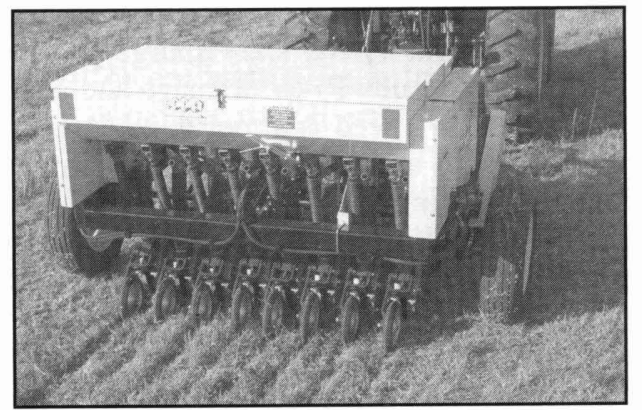

